\section{Intersections}

Canadian Journal of Music

Revue canadienne de musique
Intersections CANADIAN JOURAL OF MUSIC
REVUE CANADIENEE DE MUSIOUH

\title{
Constructing the Monk: Francis Poulenc and the Post-War Context
}

\section{Christopher Moore}

Volume 32, numéro 1-2, 2012

URI : https://id.erudit.org/iderudit/1018584ar

DOI : https://doi.org/10.7202/1018584ar

Aller au sommaire du numéro

\section{Éditeur(s)}

Canadian University Music Society / Société de musique des universités canadiennes

\section{ISSN}

1911-0146 (imprimé)

1918-512X (numérique)

Découvrir la revue

Citer cet article

Moore, C. (2012). Constructing the Monk: Francis Poulenc and the Post-War Context. Intersections, 32(1-2), 203-230. https://doi.org/10.7202/1018584ar
Résumé de l'article

Après la Deuxième Guerre mondiale, Francis Poulenc s'est intéressé à la musique de l'avant-garde française, cette dernière l'ayant amené à réagir à la fois au sein de sa musique et dans ses écrits aux expériences esthétiques et techniques de la jeune génération. Bien que la musique de compositeurs tels qu'Olivier Messiaen et Pierre Boulez n'ait pas eu un impact notable sur l'essentiel du langage musical de Poulenc, ce dernier est devenu de plus en plus conscient que le style qu'il avait développé dans l'entre-deux-guerres, défini comme léger et ironique, n’était plus en phase avec les nouvelles préoccupations et tendances critiques. L'intention délibérée de Poulenc d'adopter un caractère plus sérieux dans sa musique, caractère construit sur une thématique religieuse, une homogénéité stylistique et sur les valeurs explicitement liées de sincérité et d'authenticité, est devenue la base d'un nouveau son et d'une nouvelle "persona » qui se sont développés après la guerre et ont marqué son oeuvre jusqu'à sa mort en 1963. Le désir de Poulenc de se réinventer nous amène à réexaminer sa musique, ses écrits, certains éléments de sa vie et comment ces aspects se sont construits, afin de mieux comprendre l'émergence discursive de sa nouvelle et plus sérieuse " persona ".
Copyright ( C Canadian University Music Society / Société de musique des universités canadiennes, 2013
Ce document est protégé par la loi sur le droit d'auteur. L’utilisation des services d’Érudit (y compris la reproduction) est assujettie à sa politique d'utilisation que vous pouvez consulter en ligne.

https://apropos.erudit.org/fr/usagers/politique-dutilisation/ 


\title{
CONSTRUCTING THE MONK: FRANCIS POULENC AND THE POST-WAR CONTEXT
}

\author{
Christopher Moore
}

"At last, the world will now know that I am a serious composer!" (Mussulman 1979, 97). ${ }^{1}$ Thus reacted Francis Poulenc in 1949 upon hearing a newly released recording of his 1936 Messe under the baton of American conductor Robert Shaw. ${ }^{2}$ Certainly Poulenc was thrilled by the fact that Shaw had so lovingly rendered a work in his catalogue, which, like all of his religious music of the late 1930s, had suffered considerable neglect in the intervening years. But Poulenc's belief that this recording would help prove to the world that he was a "serious composer" should perhaps be viewed as more than simply an expression of personal contentment. Intersecting with broader issues relating both to his professional reputation and musical aesthetics, Poulenc's desire to be considered "serious" invites us to ponder a nexus of questions that constitute the focus of this article: What did Poulenc mean by serious? Why did he aspire to be viewed as a serious composer at this point in his career? And finally, how did he seek to convince critics and the general public that he was, indeed, a serious composer?

These questions would seem irrelevant, strange even, if it were not for the fact that up until the 1950s Poulenc's musical style was almost consistently defined by the very opposite of seriousness-what critic René Kerdyk, writing in 1938, described as "the personality of a jokester." As Kerdyk explained in his journalistic portrait of the composer, during the social and aesthetic "confusion" of the 1920s and 1930s, the music of Poulenc had succeeded in "enticing the public into a kind of good humour for which he holds the secret." According to the critic, Poulenc's considerable success resulted primarily from the triviality of his music and the composer's desire-viewed as increasingly suspect-to write works with the primary goal of pleasing his public. Poulenc was, Kerdyk argued, a musician "attached to homages, to gossip, and the superficial elegance of the society that surrounds him," and the critic depicted him as a materialistic entertainer "who only agrees to perform in concert if he is very well paid, like a diva" (Kerdyk 1938). ${ }^{3}$ The composer's involvement with the

1 Also quoted in Schmidt 2010, 332.

2 See Schmidt 2010, 350-51 for a list of Shaw's recordings of Poulenc's works.

3 "Il entraîne son public dans cette sorte de bonne humeur qui est son lot.... Poulenc se laisse faire, inclinant aisément au plus pur snobisme et n'attachant de satisfaction qu'aux hommages, aux petites médisances, aux soins pommadés dont l'entoure la société... Il a même la réputation d'être rapace et en quelque sorte businessman ... Il ne consent à s'exhiber au concert que grassement rétribué, comme une diva... Il se livre tout simplement à qui l'exige, avec ses dons et ses défauts, n'étant pas plus sûr des uns que des autres.... Dans notre époque confuse et sans mandat bien précis, Francis Poulenc réalise le type parfait de l'amuseur." All translations by the author unless otherwise indicated. 
sometimes impertinent early 1920 s pronouncements of the group Les Six, as well as the light-hearted, audience-friendly style and content of works such as his ballet Les Biches, or his frequently performed piano suite Soirées de Nazelles, all informed Kerdyk's view of the ostensibly superficial, capricious, and humorous ethos of Poulenc's pre-war muse.

Kerdyk's remarks, while tendentious, are not entirely misplaced. Although a noticeably melancholic streak emerged in Poulenc's musical writing, beginning with his 1929 ballet Aubade, the large majority of his works from this period do perpetuate a "masked ball" environment of fleeting impressions, abrupt encounters, and pervasive aural teasing that came to define the composer's musical style for an entire generation of listeners. It is therefore intriguing that by the close of the 1940s Poulenc felt compelled to construct a different image of himself in the public sphere, one in which the "serious composer" could coexist with or even subsume the character of the "musical jokester." By the beginning of the 1950 s some French critics recognized, and indeed contributed to, Poulenc's efforts to rebrand himself in this manner. Writing in 1950, Claude Rostand was among the first to reflect on what he viewed as the dual nature of Poulenc's musical style, describing the composer as a cross between "a monk and a vagabond," and thereby succinctly (and memorably) pointing out the antimonies of seriousness and triviality that Poulenc was increasingly juxtaposing both within individual works and across his entire oeuvre (Rostand 1950). 4

Whereas Poulenc's music of the 1950 s and early 1960 os certainly confirmed the veracity of Rostand's cliché, the professional motivations that informed Poulenc's ambition to cultivate a "serious" persona in the first place have remained unexplored. As suggested below, Poulenc was prompted to assert his "seriousness" as a result of evolving aesthetic prerogatives in postwar French musical culture. Integral to this transformation was the enlarged place given to Catholic themes in the composer's works. Although Poulenc's initial interest in religious music dated back to a 1936 visit to the shrine of the Black Virgin of Rocamadour, in the late 1940s, and following close to ten years of neglect, this interest took on new personal and professional meaning. 5 Conceived in a manner that was distinct from the religiosity of Olivier Messiaen's works and the perceived insincerity of much avant-garde practice, Poulenc's religious music would prove to be the medium through which the composer's seriousness of tone was now most readily and self-consciously invested.

As Jann Pasler has recently argued in regards to the career of Vincent d'Indy, "the story of a life, like history itself, is partly an invention. The biographer and the historian no doubt play a role in this invention, but the artist as well ... must construct and preserve his or her reputation. Reputation is the result of

4 Rostand later reflected in his obituary of the composer, "In an article I wrote a few years ago I discovered a formula of which I was quite proud and that went on to become famous since many of my colleagues have used it to death: Poulenc moine et voyou" (Rostand 1963).

5 Poulenc did write two minor religious works in 1941, the Exultate Deo and the Salve regina. Both were commissions intended to be performed at a private function that was ultimately cancelled: the marriage of his friends Georges Salles and Hélène de Wendel. 
talent, of knowledge and of acts that pique people's interest" (Pasler 2005, 369). ${ }^{6}$ In the case of Poulenc, whose posthumous legacy has been informed largely by his own autobiographical reflections, it seems particularly important to reevaluate the manner in which his public self-portrayals may have functioned as a means of orientating public opinion, of ensuring certain outcomes, and of maintaining control over his reputation as it was perceived in the public sphere.7 Poulenc's self-conscious desire to be regarded as a "serious" composer, buttressed as it was by increased dependence on the sacred, may be viewed, as I argue below, as contributing both to the preservation of his reputation and to the construction of a new persona that helped maintain the composer's relevance in the transformed cultural climate of post-Second World War France.

\section{Poulenc and the Postwar Debates}

In the immediate postwar period, few French composers could boast Poulenc's unimpeachable nationalist credentials. Politically discreet throughout the conflict, Poulenc had also given voice to his patriotism, his resistance to the German occupation, and his nostalgia for a pre-war status quo in works like the ballet Les animaux modèles, and the secular cantata Figure humaine. Conscious of his position and of his wartime reputation of being "pure and independent," Poulenc emerged from the conflict feeling quite confident about his professional prospects (Poulenc 1994, 573). ${ }^{8}$ Writing to Pierre Bernac in May 1945, he admitted that though his music might have seemed "outdated in 1932," he was convinced that in the new postwar context it was perfectly "of its time" (591)..$^{9}$ Indeed, the years following the Liberation were marked by the premiere of his first opera, Les Mamelles de Tirésias, multiple tours with Bernac, and his first (and very successful) trips to America.

Despite these professional achievements and his seemingly secure place within French musical culture, an attentive reading of Poulenc's catalogue of works reveals that the immediate postwar period (1945-49) was in fact the least productive of his entire career in terms of new compositional output. ${ }^{10}$ As Renaud Machart has outlined, the composer's inspiration was at low ebb; a completed string quartet was ultimately destroyed, a piano concerto planned for the 1946-47 season was postponed until 1949, and Poulenc left off writing mélodies, only to come back to the genre sporadically, but not always with best results (Machart 1995, 155). A year before his death in 1963, Poulenc reflected negatively on this period and declared in a radio interview that between 1945 and 1950 "I dressed too young for my age. The Sinfonietta [1947] is a new version of Les Biches [1924], but young girls [biches] that are forty-eight years old-

6 These ideas are further developed in Pasler 2007.

7 See Poulenc 1954 reprinted in Poulenc 2011; Poulenc 2006; Audel and Poulenc 1978. As Richard D. Burton has noted, Claude Rostand's description of Poulenc as "monk and vagabond" have "set the terms that have dominated critical discussion of the composer's music to this day" (Burton 2002, 15).

8 Francis Poulenc to Pierre Bernac, 27 August 1944.

9 Francis Poulenc to Pierre Bernac, May 1945.

10 See Schmidt 1995. 
that's horrible! And my Concerto for piano [1949] seems to wear sideburns and a cap tilted to the side! Stop! It's all wrong!" (Poulenc 2011, 177-78n1). ${ }^{11}$

To understand the reasons underlying Poulenc's reduced compositional rhythm, his subsequent regrets, and his emerging ambition to be viewed as a "serious" composer, it is helpful to examine the role he played within the broader aesthetic debates of the period. Poulenc's reactions to postwar developments, including the emergence of serial compositions by René Leibowitz and Pierre Boulez, the growing influence of Olivier Messiaen, as well as the continuing relevance of socialist realism for composers close to the Parti Communiste français, reveal that he was particularly anxious to defend the status quo of Stravinskian neoclassicism with which his music had become closely associated. Caught up in a postwar aesthetic flux that, as Leslie Sprout has argued, predated the hardening of musical styles around Cold War prerogatives in the early 1950s, Poulenc was forced to defend his position and thereby engaged in open conflict with a younger generation of musicians advocating for aesthetic, stylistic, and political change (Sprout 2009, 89). ${ }^{12}$ I suggest that these battles opened up Poulenc's music for critical attack, and in a context in which the hegemony represented by neoclassicism was no longer assured he was gradually compelled to seek out an aesthetic niche-a form of "seriousness" - that would prevent him from becoming marginalized within this rapidly changing cultural landscape.

Tensions resulting from generational differences erupted almost immediately following the Liberation over the French premiere of Igor Stravinsky's Danses concertantes on 27 February 1945. Students of Messiaen, including Serge Nigg and Pierre Boulez, condemned the work and rowdily renewed their disapproval at the French premiere of Stravinsky's Four Norwegian Moods performed by the Orchestre national on 15 March as part of a festival of the Russian composer's works. ${ }^{13}$ The obstreperous reaction of the "messiaeniques," as these young composers were soon called, launched a firestorm of debate in the French press (Goléa 1958, 10). Poulenc came to Stravinsky's defence and described the "pseudo-leftists" Boulez, Nigg, and André Jolivet as "yappy little dogs who hoist up their legs at the pedestal of statues," thereby publicly affirming his own continuing attachment to a pre-war status quo that had granted Stravinsky's works almost unanimous praise (Poulenc 2011, 110). As the composer boldly argued in a front-page article for Le Figaro, "All of contemporary music, French or foreign, directly or indirectly, is highly dependent upon Stravinsky's works" (111).

Attacks on Stravinsky constituted only one aspect of the generational tensions Poulenc was confronted with at this time. The growing prominence of the music of Messiaen and the development of twelve-tone music in France during this period further obliged the composer to defend and clarify his aesthetic

11 "De quarante-cinq à cinquante ans ..., je me suis habillé trop jeune pour mon âge. La Sinfonietta, c'est une nouvelle version des Biches, mais des biches de quarante-huit ans, quelle horreur! Et mon Concerto pour piano qui porte rouflaquettes et casquette sur l'oreille! Halte-là! Ça ne va plus!"

12 On music and the Cold War in France, see Carroll 2003.

13 For complete programs, see Sprout 2009, 87-88. 
stance. An important instance occurred in 1946 when Poulenc responded to a journalistic survey for which he was asked to comment on the foundations of his musical style, his compositional "principles," his use of compositional "systems," and the tension between technique and inspiration in his musical language. His responses, brief and witty (they were published under the title "Francis Poulenc, ou les prestes pirouettes") rhetorically reinforce the "irreverent" tone for which the composer (and his works) had become associated since the beginning of his career:

1. I am governed by instinct;

2. I don't have any principles, and I'm proud of it;

3. I don't have a compositional system, thank God! (systems are equal to "tricks");

4. Inspiration is such a mysterious thing that it's better not to talk about it. (Poulenc 2011, 438) ${ }^{14}$

Flippant though they may seem, these comments are perhaps best read as pointed reactions to a broad array of postwar musical developments. For example, Poulenc's off-hand dismissal of "principles" and "systems," while indicative of certain characteristics of his own aesthetic, also functioned as a thinly veiled critique of René Leibowitz's advocacy in favour of twelve-tone composition in France. Leibowitz's articles on dodecaphonism, published in Cahiers d'art in 1945, were anathema to Poulenc, and in an article written that same year for Les lettres françaises (entitled "Le musicien et le sorcier") he had confronted them head on. For Poulenc, "the Schoenberg affaire" was "finished business." He could not fathom "why in 1945 we are speaking as if the aesthetic of twelve tones is the only possible salvation for contemporary music" (Poulenc 2011, 115). ${ }^{15}$ Having attended the French premiere of Pierrot Lunaire, and having visited Schoenberg in the company of Darius Milhaud and Marya Freund in 1921, Poulenc was amazed that France's young composers could still be drawn to Schoenberg's methods, especially when, he claimed, works by Alban Berg (including Wozzeck and the Violin Concerto) had "worn out in one stroke, through the violence of genius, all the problems set by Schoenberg, and did it to such an extent that during the last twenty-five years Schoenberg's music has been nothing more than a desert, stone soup, ersatz music, or poetic vitamins" (115). ${ }^{16}$ Poulenc was also dismayed by the fact that Leibowitz's articles, later republished in his Introduction à la musique de douze sons, had been included in an issue of Cahiers d'art dedicated to "the French spiritual effort between 1940 and 1944" (116). ${ }^{17}$

14 “1. Mon canon, c'est l'instinct; 2. Je n'ai pas de principe, et je m'en vante; 3. Je n'ai aucun système d'écriture, Dieu merci! (système équivalent à 'trucs'); 4. L'inspiration est une chose si mystérieuse qu'il vaut mieux ne pas expliquer."

15 "L'on reste confondu, lorsqu'en 1945 on nous parle à nouveau de l'esthétique des 12 sons comme de la seule planche de salut de la musique contemporaine."

16 "La Suite lyrique pour quatuor à cordes, l'opéra Wozzeck, chef-d'oeuvre égal à notre Pelléas, enfin le sublime Concerto pour violon de Berg, ont épuisé d'un coup, par la violence du génie, tous les problèmes posés par Schoenberg et ceci à tel point que l'oeuvre de ce dernier, depuis vingt-cinq ans, n'est plus que désert, soupe de cailloux, ersatz de musique, vitamines de poésie."

17 See Leibowitz 1949. 
So shocked was Poulenc that he also reacted musically. The composer's very first postwar work, Huit chansons françaises, composed between August 1945 and April 1946, was written immediately following his attack on Leibowitz in Lettres françaises. Obstinately tonal and, in several instances, non-modulatory, this a cappella choral work may be viewed as a musical rebuttal of twelve-tone technique, and prefigures Igor Stravinsky's famous anti-dodecaphonic quip about experiencing "greater freedom with the number seven" (Roy 1952, 37). Based on traditional folk poems and set in a madrigalesque and primarily homophonic style, they reinforce a sense of timeless Frenchness that was in keeping with the nationalist position with which Poulenc had by then become associated. More surprisingly, however, they also reflect the contemporaneous aesthetic preoccupation of composers close to the French Communist Party, a political movement that, as a result of its close association with the French Resistance, was widely celebrated for its wartime role in "saving" the French nation. Although Poulenc was by no means attracted to Communism, it is noteworthy that in this instance the expression of his musical nationalism intersected with the folk-inspired idiom that would continue to function as a linchpin of communist socialist realism throughout the late 1940 os $^{18}$ In fact, songs like "Pilons l'orge" [Grind the barley] and "Ah! Mon beau laboureur" [Oh! My lovely worker] (nos. 3 and 7 of Poulenc's cycle), with their appeal to manual labour expressed within an entirely diatonic context, would not have been out of place in the various folk-song collections that were being concurrently edited and recorded by "Le Chant du monde," a publishing house closely linked to Communist cultural aspirations in France at this time. ${ }^{19}$

While defending himself in this manner against the threat of dodecaphonism, Poulenc also found himself embroiled in debates about the most recent music of Olivier Messiaen. Poulenc had become acquainted with Messiaen's music during the war at the "Concerts de la Pléiade," an ambitious concert series founded by Gaston Gallimard and Denise Tual. ${ }^{20}$ Two of Messiaen's most important wartime premieres took place here: Visions de l'Amen and Trois petites liturgies de la Présence Divine. Poulenc was also a regular contributor to the programs of these concerts. His Sept chansons appeared on the organization's inaugural concert on 8 February 1943, and subsequent events witnessed performances of Cocardes, the Sonata for violin and piano, Chansons villageoises, Aubade, Un soir de neige, and the French premiere of Figure humaine. When Poulenc learned that Messiaen's Visions de l'Amen was to be premiered

18 Poulenc rejected the Communist-backed Popular Front in the late 1930s and described his political leanings as that of an "an old style Republican who believes in freedom." Perhaps it was through awareness of the growing associations between folk music and Communist musical practices in France throughout the late 1940s that Poulenc abandoned obvious references to folk styles in later choral works.

19 Poulenc's former teacher, Charles Koechlin, himself sympathetic to Communist thought, also arranged a number of French folk songs throughout 1945, including the 10 chansons populaires anciennes de la Vendée, which were performed the same year by the Chorale populaire de Paris, a group whose ties with the PCF dated back to the mid-193os. Poulenc's cycle was published by RouartLerolle in 1948. On the Chorale populaire de Paris during the Popular Front, see Moore 2008.

20 See Simeone 2000. 


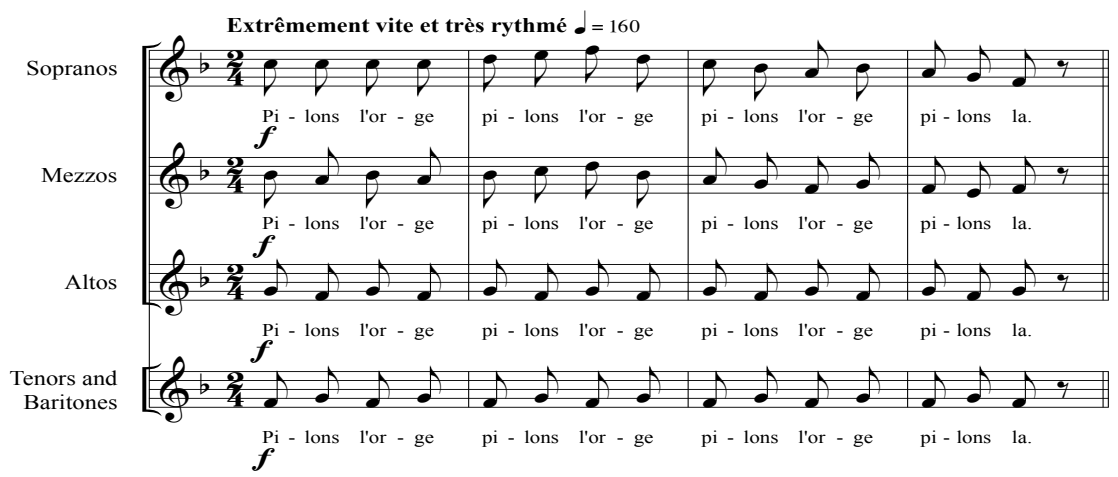

Example 1. Francis Poulenc, Huit chansons françaises, no. 3 "Pilon's l'orge," mm. 1-2

on 19 May 1943, he proceeded to openly mock the composer's religiosity. According to Tual, "When I announced to the musicians in our circle that Messiaen had been booked for the Concerts de la Pléiade, there was an outcry. Poulenc sketched, while breaking into laughter, the silhouette of a nun with her arms crossed on her stomach, singing an Ave Maria; Sauguet lightly raised his eyebrows; Désormière, who often had his nose in the air, looked sorrowful" (Tual 1980, 197). Here privately expressed among peers, Poulenc's reservations about the composer's religious aestheticism would be rendered public when the music of Messiaen provoked its own flurry of contention within the Parisian press in 1945 .

This scandal revolved around the premiere of Messiaen's Vingt regards sur l'Enfant Jésus, performed by Yvonne Loriod on 26 March 1945, and was further intensified with a performance of the Trois petites liturgies de la Présence Divine on 21 April of the same year. The "cas Messiaen," as this particular journalistic debate came to be known, was prompted primarily by Messiaen's prose writings, especially the descriptive texts accompanying his works, which brought together in such an unprecedented manner analytical explanations alongside programmatic considerations derived from a quasi-mystical appreciation of the mysteries of Catholic faith. ${ }^{21}$ The debate was also fuelled by references to the composer's Technique de mon langage musical, published in 1944. Pierre Bernac had sent Poulenc a copy of Messiaen's book in July of that year, along with a letter that foreshadowed the contentions that would plague Messiaen's music throughout the mid-1940s: "I thought I would make you laugh by sending you Messiaen's incredible book. It is sillier than anything you can imagine! Savour the style. It's funnier than [Henri] Michaux, but the message is appalling. Read the preface with its sublime ending and relish the rainbow. It's enough to turn you off augmented fourths for the rest of your life!" (Poulenc $1994,560 n 6) .^{22}$

21 For an examination of the issues, see Hill and Simeone 2005, 142-75.

22 Pierre Bernac to Francis Poulenc, 5-7 July 1944: "J’ai pensé vous faire bien rire en vous envoyant l'incroyable bouquin de Messiaen. Cela dépasse en bêtise tout ce que l'on peut imaginer! Savourez le style. C'est plus drôle que du Michaux mais le fond est affligeant. Lisez la préface dont la fin est 
Similar criticisms dominated the reception of the Vingt regards, a work in which Messiaen's theoretical principles and mystical leanings were expressed in what Bernard Gavoty facetiously referred to as the composer's "notices inexplicatives" (Gavoty 1945, 30). In Gavoty's opinion, Messiaen was "fooling his audience" and his approach lacked sincerity. According to the critic, the composer's "laborious system," exposed in the Technique de mon langage musical, simply constituted a repertory of technical procedures that allowed the composer to give the illusion of being capable of representing mystical moments that, in fact, "he doesn't understand any better than we do." For Gavoty, the theoretical apparatus found in Technique de mon langage musical was nothing more than a musical "cookbook" and proved that Messiaen favoured systematization above instinct, and sterile calculation above sincere individual expression (21-37).

Gavoty was not the only critic to express his exasperation with Messiaen's theoretical explanations. Marc Pincherle openly appealed to the composer to "come back down to earth" and to write a work "which needs nothing except the music, seeking a path to the All-Powerful by its musical virtues alone. That was Bach's way, which was a pretty good path you have to admit" (Pincherle 1945). Claude Rostand was more malicious, referring to Messiaen's literary approach as nothing but "lies and sacrilege," and, in reaction to a 1945 performance of Les Corps glorieux, described the composer's commentaries as little more than reprehensible "gobbledegook" (Rostand 1945). As for Poulenc, writing to Henri Sauguet, he made fun of the Vingt regards by playfully suggesting that he thought about giving his recently composed Histoire de Babar the subtitle "eighteen glances at the tail of a young elephant" (Poulenc 1994, 603). ${ }^{23}$ When asked in 1946 to make a public pronouncement about the "cas Messiaen," his response appropriated elements that reflected the concerns (as well as the imagery) of the aforementioned critics: "Though I totally disapprove of Messiaen's writings as well as the recipes in his composition treatise-the only good recipes being those, according to me, that you use in the kitchen-I would never think of denying him the leading position that he currently holds in contemporary art" (Poulenc 2011, 440). ${ }^{24}$

Just as he had denounced the systematization of twelve-tone technique in the hands of Leibowitz, Poulenc-though he generally admired Messiaen's music-was unable to take his aesthetic system of "unimaginable" literary commentaries seriously (Poulenc 1994, 602). ${ }^{25}$ As such, Poulenc's 1946 statements in Contrepoints about composing in the absence of "systems" and "prin-

sublime et gargarisez-vous d'arc-en-ciel. C'est à vous dégoûter des intervalles de quarte augmentée pour le restant de vos jours."

23 Poulenc to Henri Sauguet, 9 August 1945: "J'ai achevé l'orchestration des Mamelles et ma suite de piano Babar pour laquelle je pensais au sous-titre suivant: dix-huit coups d'œeil sur la queue d'un jeune éléphant."

24 "Bien que désapprouvant totalement la littérature de Messiaen autant que les recettes de son traité de composition, les seules recettes utiles, étant, selon moi, celles de cuisine, il ne me viendrait pas un instant à l'esprit de nier la place de premier plan qu'occupe aujourd'hui ce musicien dans la production contemporaine."

25 Poulenc to Yvonne Casa Fuerte, 30 July 1945. 
ciples," while perhaps indicating something of his own compositional methods, should perhaps first be read as a response to contemporaneous trends that he did not unconditionally approve. By opting for a humorous, unpretentious and pithy exposition of his ideas, Poulenc reinforced qualities of his persona that were already well known, while concomitantly revealing his defensiveness with regards to these most recent aesthetic and technical developments. Aware that the music of the younger generation was transforming critical alliances at this time, Poulenc was also careful to take advantage of whatever critical support he could find. Given their public attacks against Messiaen and his students, it is perhaps not surprising that Poulenc now began to actively cultivate relationships with both Bernard Gavoty and Claude Rostand. As examined below, although Gavoty would soon cause the composer problems of his own, Rostand-one of Messiaen's most vociferous critics-became a steadfast ally who would play a crucial role in reorienting public opinion about Poulenc's works and aesthetics in the years to follow. ${ }^{26}$

\section{REACTING THROUGH WORK}

Poulenc's involvement in these debates, and his advocacy for aesthetic and stylistic continuities with the pre-war period, was largely reflected in his music during the late 1940s. Overtly engaging with themes of loss and commemoration, his works were primarily retrospective in tone; not only did some of them (like the 1947 Sinfonietta mentioned above) draw closely upon the style of his earlier works, others revealed an important inspirational debt to friends and cultural acquaintances who were no longer alive. ${ }^{27}$ Particularly interesting in this context was Poulenc's choice to memorialize in song two fallen cultural heroes of the Resistance: poets Robert Desnos and Gabriel Garcia Lorca. While there is no reason to question the sincerity of these homages, Poulenc's works also fulfilled the ancillary function of reinforcing his patriotic stance during this period. By setting the works of individuals who had been killed at the hands of the Nazis, Poulenc allied himself with the legacy of the Resistance, and thereby reiterated a form of cultural patriotism that was notably absent from many of the younger generation's attempts to reconfigure musical culture at this time.

Take, for example, Poulenc's 1946 mélodie "Le disparu," a setting of Robert Desnos's wartime poem "Couplets de la Rue Saint-Martin." Here, the composer conjoins themes of political resistance, memory, and loss while articulating strong aesthetic continuities with the musical and urban zeitgeist of the 1920 s and 1930s. Desnos's poem, published in 1943, was written following the sudden disappearance of his friend André Platard, a Resistant who was captured and eventually assassinated by the Germans. The poem laments Platard's disappearance from the rue Saint-Martin and employs unsentimental and direct

26 Rostand's attitude about Messiaen changed throughout the 1950s and he later regretted having attacked the composer so ferociously during the "cas Messiaen." See Rostand 1957.

27 See, for example, "Paul et Virginie" based on a poem by Raymond Radiguet (died in 1923), or "mais mourir" written in memory of Nusch Éluard (died in 1946). 
language ("Je n'aime plus la rue Saint-Martin") to create an atmosphere of understated and repressed grief. Recalling their shared existence ("Nous partagions la chambre et le pain") and the closeness of their bond ("C'est mon ami, c'est mon copain"), the emotional charge of the narrator's loss is paradoxically heightened by the frugal, even banal, language used to express it.

Poulenc's setting imposes a further layer of grief and memory to this poetic scenario. Like André Platard, Desnos himself was arrested by the Germans and eventually succumbed to dysentery at the Theresienstadt internment camp. His body was repatriated to France in 1945, and the event received considerable attention in the press as a means of underlining Nazi wartime atrocities. As such, when "André Platard" is evoked in Poulenc's song, he serves the added cultural function of representing yet another "disparu": that of Robert Desnos himself. Despite this tragic network of associations, and the contained, almost numb suffering expressed in Desnos's couplets, Poulenc's music focuses primarily on evoking the activity and heady atmosphere of the busy rue SaintMartin. As the composer wrote in his Journal de mes mélodies, in an apparent attempt to match the poem's rhetorical familiarity, "Le disparu" borrows from musical styles associated with the chanteuse de rue, Édith Piaf. Atop a gently lilting rhythm of a "Boston waltz," Poulenc conjures up images of "the dance with the accordion band, the peal of bells," and, somewhat less convincingly, what he described as "the funeral march" (Poulenc 2006, 85). Indeed, whereas Desnos's poem evokes a bleak street tragically bereft of one of its beloved pedestrians, Poulenc's setting wistfully restores animation and life to it, the tolling chords in the upper register of the piano serving as an aural reminder of the imposing church towers ("Saints Merri, Jacques, Gervais et Martin") that demarcate its physical boundaries within the Parisian cityscape.

"Le disparu" not only illustrates Poulenc's attentiveness to an ethos of patriotic mourning and commemoration; the informality of the song's musical language also reinforced the composer's positioning via the press as a figurehead for aesthetic continuity with the pre-war period. Indeed, despite the palpable flowering of a more introspective form of nostalgia, throughout these early postwar years Poulenc continued to be publicly defined through those stylistic characteristics (such as humour, impertinence, and playfulness) with which his early career had been assured. ${ }^{28}$ Even the first French performance of Figure humaine, a work composed in 1943 and later described by critic André Schaeffner as evoking the "suppressed violence" of the Occupation, was unable to substantially modify this aspect of the composer's reputation (Schaeffner 1998, 219). ${ }^{29}$ Performed for the first time in France on 22 May 1947, it was programmed alongside works by Franco-Flemish masters of the early Renaissance,

28 For an examination of nostalgia in Poulenc's works, see St-Aubin 2008.

29 The article was originally published as "Francis Poulenc, musicien français," Contrepoints (January 1946): "Les choeurs de Poulenc ... évoquent des tons de fresque, aux violences étouffés." Employing an English translation of Paul Éluard's poems by Roland Penrose, Figure humaine was premiered and broadcast by the BBC Home Service on 25 March 1945. The first performance using the original French texts was conducted by Paul Collaer in Brussels on 2 December 1946. For a discussion of the symbolic importance of this work for the BBC, see Launchbury 2012. 
including Guillaume Dufay, Johannes Ockeghem, Josquin Baston, and Gérard de Turnhout. Employing a double a capella choir, indulging in blunt chromaticisms, and abounding in unconventional harmonizations, the composer was fully aware that the work was "terribly difficult." ${ }^{\circ}$ Whatever the challenges, Poulenc referred to the Parisian performance as a "great success," and this despite the fact that critical reception was thin and not always complimentary (Poulenc 1994, 638). ${ }^{31}$ Louis Aubert complained that the composer did not always "follow the rhythm, the flow of the poetry." 32 Nadia Boulanger, on the other hand, described the work in terms of Poulenc's pre-war compositional trademark of stylistic diversity and praised the way in which the composer had incorporated musical clichés that were derived largely from sixteenth-century polyphonic music.33 For Parisian critics, Figure humaine was viewed as exceptional in terms of the composer's output; understood less as outlining a change of direction in the composer's musical style, the sobriety and earnestness of the work were viewed solely as a one-time reaction to the social and political turmoil of the Occupation. As the composer Henri Sauguet remarked, Figure humaine "belonged to a series of works by French musicians that were written in a groundswell of internal revolt as well as faith and hope in the future."34 The special circumstances of the Occupation and Resistance were therefore crucial to understanding not only the work's poetic message, but also its uncharacteristic style and affect in comparison to Poulenc's better known works. Indeed, having received only one French performance between the end of the war and 1958, Figure humaine, while perhaps reinforcing Poulenc's patriotic credentials in the postwar period, did very little to alter critical appreciations of his musical language.

If there were any questions about whether Poulenc was striking out on new and ostensibly more "serious" stylistic paths, they were momentarily but thoroughly laid to rest following the high-profile 1947 premiere of his operabouffe, Les Mamelles de Tirésias. Here, in a work also composed during the war, Poulenc's wit and frivolity were reasserted with impressive panache. 35 While writing the piece, Poulenc compared it to his spirited Bal masqué of 1932 and noted that "something funny is always taking place" (Schmidt 1995, 352-53). As Claude Rostand wrote in his glowing review for Carrefour, the Mamelles comprises "colossal gaiety, belly laughs, nightmarish burlesque, the most reckless irreverence, and at the same time the swiftest and lightest humour." In

\footnotetext{
30 Handwritten note by Poulenc in the BBC Written Archive Centre, cited by Launchbury 2012, 162 .

31 Poulenc to Darius Milhaud, 11 June 1947.

32 Louis Aubert, "Deux manifestations," press clipping, n.d., Poulenc 1919-63.

33 Nadia Boulanger, "Figure humaine de Francis Poulenc," press clipping, n.d., Poulenc 1919-63.

34 Henri Sauguet, untitled and undated press clipping, in Poulenc 1919-63: "Elle appartient à cette série d'ouvrages que des musiciens français ont écrits dans un mouvement de révolte intérieure et aussi d'espérance fidèle."

35 The score is dated "May-October 1944" and was thus begun before the Liberation of Paris. Poulenc's letters indicate that he had begun planning an opera on this subject before the beginning of the Second World War. See Schmidt 1995, 351.
} 
sum, this was, Rostand claimed, "Poulenc at his best" (Rostand 1947)..$^{6}$ If the work did manage to elicit some criticism, it was only because the patrons of the Opéra-Comique, described by one reviewer as "devotees of [Puccini's] Bohème," had been "offered a gin fizz [in the] place of a cup of camomile tea" (Palamède 1947). ${ }^{37}$ Ultimately the reception surrounding this farcical wartime work further reinforced characteristics of the composer's style that had been operative since the early $1920 .^{38}$

By 1949, however, Poulenc's heavy reliance upon his pre-war muse began to encounter strong resistance within the critical community, most notably so when his works were explicitly compared to those of the rising stars of the younger generations. The reception surrounding the French premiere of Poulenc's Piano Concerto is a case in point. Performed at the Third Aix-enProvence Festival on 24 July 1950, the Concerto followed on the heels of the French premiere of Olivier Messiaen's newly composed Turangalîla-Symphonie, a work that, like Poulenc's Concerto, had received its world premiere in Boston some months earlier. ${ }^{39}$ Even former allies of Poulenc, like Bernard Gavoty, poked fun at the composer's lightweight musical inspiration, reproaching him for "having intentionally chosen some of the most banal harmonies around," and suggesting that the Concerto, with its "simple strand of songs, worn-out refrains, and puffs of operettas" was "not at all a concerto, but a tiny portrait of manners in the hand of a petit maittre" (Gavoty 1950)..$^{\circ}$ Antoine Goléa, a staunch defender of Messiaen's work, derided the Concerto's "scholastic spirit" and the composer's "choice of themes that relies almost exclusively upon citations ranging from Wagnerian fragments to quite undistinguished Parisian tunes." ${ }^{11}$ Critic Pierre Meylan concurred, citing "the mediocrity of themes that lack life, a burlesque style that is not always funny, and an inspiration that runs out of breath." Despite the presence of Poulenc's characteristic "insouciance and wit," Meylan concluded that it would be "in vain to look for anything profound" in this Concerto. ${ }^{42}$ Ultimately, the negative critical reception to the work also reinforced the recent attacks Poulenc had endured at the hands of influential critic and musicologist Émile Vuillermoz. In his widely read Histoire de la Musique, published in 1949, Vuillermoz famously described Poulenc

36 Quoted and translated in Downes 1947.

37 Ibid.

38 In a letter to Pierre Bernac, 22 July 1944 (Poulenc 1994, 561), Poulenc wrote about the Mamelles: "To say that it is new Poulenc: no, but that is inevitable because of the similarity between Apollinaire's verses and so many of his poems that I have set to music."

39 The world premiere of the Piano Concerto took place in Boston on 6 January 1950; the Turangalîla-Symphonie was first performed there on 2 December 1949.

40 "Une simple chaîne de chansons, de refrains usés, de bouffées d'opérettes, pour mieux créer l'ambiance, facile et veule. Quel doigté dans l'évocation!" “Certes, il ne s'agit nullement d'un concerto, mais d'un tableautin de mœurs enlevé de main de petit maître.”

41 Antoine Goléa, "Premières auditions," press clipping, n.d., Poulenc 1919-63: "Un esprit trop collégien dans le choix et mélange de thèmes qui sont presque exclusivement des réminiscences allant de fragments wagnériens à des rengaines parisiennes vraiment peu distinguées."

42 Pierre Meylan, "Le Troisième festival musical d'Aix-en-Provence," Gazette de Lausanne, press clipping, n.d., Poulenc 1919-63. "La médiocrité des thèmes qui tournent court, un burlesque qui n'est pas toujours drôle, une inspiration vite essoufflée.... Il ne faut pas y chercher de la profondeur." 
as an "abbé de cour," a fashionable socialite whose music was "as complacently salonnier and as anxious to please as that of Reynaldo Hahn" (Vuillermoz 1949, 456). ${ }^{43}$ As Meylan stated, the Concerto was the "culmination of a period of the composer's development that has not been extremely glorious; in it we find everything that contributed to the success of this gifted musician who is too easily satisfied with himself." 44

Those closest to the composer naturally came to his defence, and a war of words quickly ensued between Poulenc's and Messiaen's supporters. Indeed, for Poulenc's devotees, the lighthearted side of the composer's new "casual concerto" (or "concerto en casquette" as the composer described it) was deemed a welcome contrast to the modernist formulas, abstractions, and aesthetic posturing that characterized so much postwar music. Hélène Jourdan-Morhange contrasted the works of Poulenc and Messiaen along these lines. She criticized "the grandiose literature that surrounds Messiaen's music just like the halo that surrounds the person" and was bothered by Messiaen's "auto-admiration" and the fact that he was "already being mythologized during his own lifetime." Unlike the Turangalîla-Symphonie, which Jourdan-Morhange viewed as derivative and unnecessarily complex, Poulenc's Concerto was "authentic," the work of an artist who "composes music that suits him, without dogmas and theories." "During these complex times," she added, Poulenc's Concerto "almost seems too simple! The themes are pretty (as devoid of 'vulgarity' as the ones people used to criticize in Chabrier's music) but even if it is easy music, at least we can call it music."45

Claude Rostand was also quick to defend the work and equally urged his readers to acknowledge the "sincerity" of Poulenc's inspiration, writing that in the Concerto the composer "was being himself, but what is most extraordinary is that there are people ready to condemn him for it, either to his face or behind his back." 46 According to Rostand, the critical attacks directed against Poulenc's music were the combined result of misunderstanding and bad faith, and were upheld by individuals who clung to the view that the composer was an outdated and frivolous relic of the 1920s. The critic worked hard to challenge this pervasive stereotype: "There are two people in Poulenc: there is, if I dare say, a bit of the monk and a bit of the vagabond. It's the second one who wrote the new concerto. A bad boy, sensual and affectionate, saucy and tender,

43 See Poulenc to Daniel-Lesur, 23 February 1950, in which he reacts to Vuillermoz's description (Poulenc 1994, 680).

44 Pierre Meylan, "Le Troisième festival musical d'Aix-en-Provence," Gazette de Lausanne, press clipping, n.d., Poulenc 1919-1963. "C’est un aboutissement d'une période qui n’a pas été chez Poulenc extrêmement glorieuse, on y retrouve tout ce qui a fait le succès de cet auteur doué, mais trop vite content de lui."

45 Hélène Jourdan-Morhange, "Deux premières auditions européennes dans le cadre du festival d'Aix-en-Provence," Les Lettres françaises, press clipping, n.d., Poulenc 1919-63. "Poulenc est authentique. Il compose la musique qui le requiert, sans dogmes et sans théories ... et dans notre temps de complications, cela semble trop simple! ... Les thèmes sont jolis (aussi peu "vulgaires" que l'on reprochait jadis à Chabrier) et si c'est de la musique facile c'est en tout cas de la musique."

46 Claude Rostand, "Le concerto de Poulenc," press clipping, n.d., Poulenc 1919-63. "Il a donc été lui-même; mais ce qu'il y a de singulier, c'est qu'il s'est trouvé des gens pour le lui reprocher, à voix haute et basse." 
gracious and abrupt, aristocratic and popular, and who has an infinite amount of distinction in his working-class accent" (Rostand 1950). 47 In another review of the work, Rostand expanded on these ideas, insisting that Poulenc was not only the "impertinent or even disrespectful composer of Les Biches, the Bal masqué, [and] the Chansons gaillardes," but also a "severe and grave musician," who is "not ashamed of his emotion and who is capable of attaining greatness" (Poulenc 1994, 693).

Despite these attempts to defend Poulenc and his work, the critical reaction surrounding the Concerto was a clear indication that the near-unanimous praise Poulenc had enjoyed since the mid-192os could no longer be taken for granted. It also placed him squarely on the losing side of a comparison that, as a result of having new works programmed in close proximity and at the same venue, pitted his music against that of Olivier Messiaen. Poulenc himself reacted to the debate in private, describing the Turangalila-Symphonie in a letter to Milhaud as "atrocious"- "a work written for the masses and the elite, the bidet and the holy water font, and all of it in the dreadful manner of [Paul] Dukas and Marcel Dupré" (Poulenc 1994, 695).48

Although Poulenc consistently denied it in the press, the Stabat Mater, begun immediately following the Aix-en-Provence festival, may be viewed as a reaction to the debacle of the Piano Concerto and as a self-conscious effort to assert a form of musical "seriousness" in the face of an increasingly skeptical critical community. In doing so, Poulenc also made a decisive move to lay claim to an unexploited aesthetic niche in the expression of the spiritual in contemporary French musical practice. Indeed, while the composer was writing the Stabat Mater he described it as being free of "formulas" and "redundancies," and far removed from the "dishonesty" of Messiaen's musical aesthetics. Unlike Messiaen's music, which Poulenc and his supporters viewed as too discursively flamboyant and stylistically diffuse, Poulenc aimed for both understatement and stylistic homogeneity in the Stabat Mater in a manner that underlined a purportedly humanist goal of touching "the crowds that like to pray" (Poulenc 1994). ${ }^{49}$ The work was conceived as a tribute to Poulenc's friend, the artist and decorator Christian Bérard who had died in February 1949. Unlike Messiaen's works such as the Visions de l'Amen or the Vingt regards, Poulenc's cantata was conceived within the most orthodox traditions of Christian prayer and in the absence of any type of literary program. By writing music that "sounds like Bach as if he had been taught by Schubert," the composer asserted his stylistic indebtedness to centuries-old traditions of religious music (Gavoty 1951).50

47 "Le moine et le voyou. Il y a deux personnes chez Poulenc: il y a, si j’ose dire, du moine et du voyou. C'est le second qui a signé le nouveau concerto. Un mauvais garçon, sensuel et câlin, polisson et attendri, gracieux et brusque, aristocrate et peuple, et qui a infiniment de distinction dans l'accent faubourien."

48 Francis Poulenc to Darius Milhaud, 6 September 1950: "Cette oeuvre écrite pour la foule et l'élite, le bidet et le bénitier, tout ceci dans une affreuse tradition Dukas, Marcel Dupré."

49 See Poulenc to Pierre Bernac, 29 August 1950; Poulenc to Marguerite Long, 30 August 1950: and Poulenc to Darius Milhaud, 6 September 1950.

50 Bernard Gavoty, "Au festival de Strasbourg : Poulenc contre Rossini?," press clipping, n.d., Poulenc 1919-63. 
Like Pergolesi before him, the composer opted for a twelve-movement organization of the hymn's twenty stanzas. The work's conventional orchestration, five-part choral writing, and use of a soprano soloist (with a "warm, Italian" voice, according to the composer) further reinforced ties to traditional musical settings of the text (Poulenc 2011, 606). As critic René Dusmesnil wrote in Le Monde, the form of the Stabat Mater "is purely classical: it is a prayer, a fervent prayer expressed with ardour, but without searching for an original musical style" (Dumesnil 1951).51 Poulenc, who was surprised at the speed with which he composed the work, held the Stabat in high esteem, claiming that it was "profoundly authentic" (Poulenc 1994, 698).52

Critics and audiences certainly appreciated what they viewed as the sincerity of the composer's approach. As one critic noted, there was no "heresy" in the Stabat Mater; the irreverence one habitually found in Poulenc's "profane" works was here entirely absent (Zed 1951). Writing about the work's Strasbourg premiere, and taking a swipe at the dodecaphonists, Denis Hermant concluded that "the music comes from the heart and is not music by an engineer." 53 Marc Pincherle also lauded the "authenticity and the sincerity" of Poulenc's conception, a comment that must be viewed in terms of the critic's disillusionment with the highly theorized practices of both Messiaen and Leibowitz. ${ }^{4}$ Writing about a 1953 performance, Jacques de Colombier argued that what was original in Poulenc's work was less the musical means employed than "his desire to bring out the human dimension in the drama of the Mater Dolorosa" (Colombier 1953).55 Bernard Gavoty began by teasing Poulenc about how the Stabat seemed to have been composed to "make up for past sins" (i.e., the Concerto), but concluded that the composer's about-face was ultimately convincing. By seamlessly moving from the worlds of the "flat cap to the halo," from the Mamelles to the Stabat, Poulenc revealed that he was a "Homo duplex" and not at all as easy to pigeonhole as many had been led to believe (Gavoty 1990, 91).

The high-profile performances and vast popularity of the Stabat Mater were entirely unprecedented in Poulenc's previous sacred output. ${ }^{6}$ The work was first performed in Strasbourg in 1951 and was followed up by back-to-back performances in New York and Paris in 1952. The Paris premiere, held on 30 April 1952, inaugurated the Oeuvre du XXe siècle, an important festival organized by Nicolas Nabokov, secretary general of the anti-communist Congress for Cultural Freedom, an organization that received financial backing from the CIA.

51 "La forme en est purement classique: il s'agit d'une prière, et d'une prière fervente; elle s'exprime avec ardeur, mais sans recherches d'aucune singularité d'écriture."

52 Francis Poulenc to Pierre Bernac, October 1950: "Un froid coup d'oeil m’a prouvé ce matin que c'est bien, parce que profondément authentique."

53 Denis Hermant, "Des milliers d'auditeurs acclament Francis Poulenc," press clipping, n.d., Poulenc 1919-63: "Une musique qui vient du cour et non pas une musique d'ingénieur."

54 Marc Pincherle, "La Musique," press clipping, n.d., Poulenc 1919-63: “Une musique religieuse profondément recueillie, dont la sincérité et l'authenticité ne font pas doute davantage.”

55 "L'originalité du compositeur semble consister dans sa volonté de ramener le drame de la Mater Dolorosa à sa dimension humaine."

56 The work was awarded the New York Critics' Circle Award for Best Choral Work of the year in 1952. 
As Marc Carroll has examined, Cold War political and aesthetic prerogatives weighed heavily on programming decisions for the Oeuvre du XXe siècle, with those Western composers who had been condemned by the Soviets, or those Soviet composers who had faced official sanction in their homeland dominating the festivities. 57 Poulenc's pro-Americanism had been tacitly asserted throughout the late 1940s. Premiered in Boston in 1950, the much-maligned Piano Concerto, replete with tango rhythms and snippets of Negro spirituals, was later described by the composer as a type of "handshake" with America"a country that currently constitutes-and by far-my largest and most faithful public" (Poulenc 2011, 802). Poulenc's aesthetic and professional interest in America, along with the ideological malleability of the Stabat, facilitated the work's symbolic appropriation in the anti-Soviet message of the Oeuvre du XX siècle. The Parisian performance was dedicated to "the martyrs of all twentieth-century tyranny," and political refugees from the Soviet Union filled the Église Saint-Roch to listen to the Stabat Mater alongside the works of J. S. Bach. A celebration of Christian culture that implicitly condemned the godlessness of Communist regimes, the concert asserted deep continuities between past and present in works that emphasized humanist values. Claude Rostand even went so far as to say that Poulenc's Stabat, in its "richness and ornateness," held close aesthetic affiliations with seventeenth- and eighteenth-century art, thereby making the pairing of the work with Bach's Magnificat and the cantata, "Bleib bei uns, den es will Abend warden," all the more felicitous. ${ }^{8}$

\section{Autobiographical Constructs}

Following a career of three decades during which he had been viewed primarily by the critical establishment as a petit maitre, Poulenc took advantage of the success of the Stabat Mater to reorient public opinion and to assert the "seriousness" of his compositional intent. Indeed, throughout the 1950 os Poulenc focused his efforts on debunking critical portraits that painted him as an "abbé de cour" - a composer attached to easy success and aristocratic patronage. Religious works like the Stabat, or religious-themed works, like Dialogues des Carmélites, would be integral to this transformation and would be accompanied by a reinterpretation of his achievements that would now place considerable and unprecedented importance upon the lesser-known religious works of the 1930s, such as the Litanies à la vierge noire and the Messe. With growing criticism directed at his postwar works, Poulenc now looked back to this earlier period and took advantage of a source of inspiration that could better serve him in the postwar context.

Ever aware of the role of the press in shaping public opinion, Poulenc did not let his music do all the talking. Integral to the construction of his "serious" reputation was the series of radio interviews he recorded with his most important critical advocate of the late 1940 s and early 1950s, Claude Rostand.

57 See Carroll 2003.

58 Claude Rostand, “Ouverture symbolique de L'Oeuvre du XXe siècle," Carrefour (May 1952). Press clipping, n.d., Poulenc 1919-63. 
Broadcast on French Radio between 13 October 1953 and 16 February 1954, they were soon after published as Entretiens avec Claude Rostand (Poulenc 1954).59 Organized in eighteen parts, these interviews were the first major examination of the composer's life and works, and it is clear that Poulenc viewed them as an important means of influencing critical opinion. In a letter written to his close friend Darius Milhaud, Poulenc alluded to his extensive preparation for this project as well as its professional significance: "I go to sleep at 9 and get up at 6 . Then I start to write ... my interviews with Claude. I attach the utmost importance to this occasion, which will provide us with the opportunity to explain things" (Poulenc 1994, 746n4). ${ }^{60}$ As this letter clarifies, Poulenc's interviews with Claude Rostand were not improvised conversations, but rather carefully prepared public performances. Crafted in a manner typical of many interviews during this period, Poulenc composed the text in the style of a theatrical play, and both interlocutors rehearsed their spoken "parts," which in this case produced a quick-moving though somewhat stilted on-air delivery. ${ }^{61}$ As the reviewer Emmanuel Buenzod wrote in reference to Poulenc's autobiographical exercise, "What is really interesting here is the very French art of elucidation, the nimble and charming way of dealing with all types of subjects, from the most serious to the most superficial, and to say only what is appropriate in a tone that varies from casual elegance to real engagement."62

The goal of these interviews was, as Rostand outlined in his argumentative introduction to the published version, to confront head-on the "extreme prejudice" and the "satisfied contempt" that routinely accompanied critical characterizations of Poulenc as a "petit maître." Those endorsing this view, Rostand fumed, did not recognize or even care to admit that Poulenc's music, especially his sacred works, contains "serious, even austere" elements (Poulenc 2011, 744). To reinforce his thesis, Rostand's preface proposes a short character sketch of the composer in which Poulenc is described not as a superficial "abbé de cour" but rather as an "anxious and self-critical" composer, and one who is "always ready to analyze himself in order to develop self-knowledge" (744). In a word, he was a "serious" composer. Poulenc, as author of the Entretiens, was naturally complicit in this argumentative strategy. Later in the volume, he endorsed Rostand's assessment of him as embodying the contrasting characteristics of a "monk and a vagabond" and claimed that "I am not only the light-hearted composer of Les Biches and Les mouvements perpetuels" (790). Indeed, the Entretiens, dedicated as they were "to shining a light on the true silhouette of the artist," made the first sustained argument in favour of Poulenc's "serious"

59 They have been republished in Poulenc 2011, 741-838.

6o Francis Poulenc to Darius Milhaud, 28 January, 1953: "Me couchant à 9 heures, je suis debout à 6. Je me mets alors à écrire ... mes entretiens avec Claude. J'attache la plus grande importance à cette occasion qui nous est donnée de nous expliquer" (ellipsis in original). Milhaud had published his own collection of interviews with Claude Rostand a year earlier; see Milhaud 1952.

61 See Haine 2004, 160-61, for a discussion of how these kinds of interviews were prepared.

62 Emmanuel Buenzod, "Radio-Poulenc," press clipping, n.d., Poulenc 1919-63: "Ce qui retient ici, c'est plutôt l'art très français de l'élucidation, la façon preste et charmante d'aborder successivement tous les sujets, des plus sérieux aux plus frivoles et de n'en dire que ce qu'il convient, à michemin entre le détachement élégant et l'engagement réel." 
side, an element of the composer's personality that was presented as being at the antipodes of the one that had been expressed in the 1949 Piano Concerto (745). As J. P. Robert wrote in his review of the book, the Entretiens revealed an unknown side of the composer: "his critical sense, his lucidity, and the severity with which he judges himself and the ability he has for self-criticism as a means to better know and understand himself. Those who cannot forgive the banality and vulgarity with which the author of Aubade at times filled his music are, in light of this book, going to cry foul" (Robert 1954). ${ }^{63}$

The Entretiens also permitted Poulenc to further clarify his position with regard to contemporary debates. Emphasizing the sincere and authentic nature of his musical inspiration, the composer predictably lashed out at any of his contemporaries whose music seemed dependant on systematization and abstraction. For example, Poulenc reiterated his critique of Messiaen, acknowledging that the composer was capable of moments of genius but denouncing his "pseudo-Hindu language that brings together late-style symbolism derived from René Ghil or from Saint-Pol Roux." Insisting that none of his own music was written as a result of "aesthetic premeditation," Poulenc affirmed that in their religious offerings he and Messiaen did not "genuflect in the same way." Indeed, even in terms of his religious works, Poulenc argued that they were unclassifiable and could not be associated with any specific aesthetic courant such as "pure mysticism, symbolist mysticism, realism, etc." (Poulenc 2011, 793).

An integral part of Rostand and Poulenc's argumentative strategy was to tell the history of the composer's musical development by placing considerable emphasis on works that had hitherto been neglected by the majority of the critical community: his religious music. Two chapters of the Entretiens were devoted specifically to this question, and recorded excerpts of some of these works were broadcast over the air. Key to underlining the authenticity and sincerity of Poulenc's religiosity was the composer's evocative description, never before revealed in a public forum, of the events that led to his return to Catholicism and his concomitant interest in sacred composition:

In 1936, a crucial date in my life and in my career, while involved in rehearsal sessions with Yvonne Gouverné and Pierre Bernac in Uzerche, I asked the latter to drive me to Rocamadour, about which my father often spoke. This site of pilgrimage is in fact very close to the Aveyron. A few days earlier I had just learned about the tragic death of my colleague Pierre-Octave Ferroud. The dreadful decollation of this energetic musician stopped me in my tracks. Thinking about the fragility of our human state, spiritual life attracted me once again. Rocamadour succeeded in bringing me back to the faith of my childhood. This sanctuary, certainly the oldest in France (Saint-Louis stopped there on his way to the Crusades), had everything to captivate me. Bathed in sunlight and clinging onto a vertiginous anfractuosity of rock, Rocamadour is a place

63 "C'est un des traits les plus attachants que nous révèle Poulenc que son sens critique, sa lucidité, la sévérité dont il fait preuve vis-à-vis de lui-même et la faculté qu'il a de s'analyser pour se mieux connaître et se mieux comprendre. Ceux qui ne peuvent pardonner la banalité et la vulgarité dont l'auteur d'Aubade a parfois nourri sa musique vont ici crier au scandale." 
of extraordinary calm that is all the more emphasized as a result of the very small number of tourists. Preceded by a courtyard, all pink from the potted oleander, a quite modest chapel, half constructed in the rock, houses a miraculous statue of the Virgin, sculpted, according to tradition, in black wood by Saint Amadour, the little Zacchaeus of the Gospel who had to climb a tree in order to see Christ. The very evening of this visit to Rocamadour I began my Litanies à la vierge noire for woman's voices and organ. In this work I tried to render the atmosphere of "peasant devotion" that had so struck me in that place... Since that day, I have often returned to Rocamadour, placing under the protection of the Black Virgin diverse works like Figure humaine, the Stabat to the memory of my dear Christian Bérard, and, most recently, the opera that I have begun based on Dialogues des Carmélites by Bernanos. You now know, my dear Claude, the true inspiration behind my religious works. (Poulenc 2011, 790-91) 64

Poulenc's account is striking for a number of reasons, including the way in which he enshrines his religiosity within a historic monument to French Catholicism, as well as how he deflects attention from his personal transformation by emphasizing the aesthetic appeal of this religious sanctuary. Jane F. Fulcher has read Poulenc's narrative, and the composer's interest in "peasant devotion," as an indication of the his alignment with right-wing aesthetic values at the end of the 1930s (Fulcher 2005, 261-65). Richard Burton, on the other hand, views Poulenc's epiphany as a "psychological-spiritual transformation," claiming that the composer experienced in the figure of the Black Virgin "a possibility of metamorphosis" that would have wide-ranging implications on subsequent works (Burton 2002, 73-75). Further interpretations are certainly possible; for example, the growing presence of fervent Catholics in Poulenc's professional circle (such as Gouverné and Nadia Boulanger), the cultural significance of Catholic "conversion" (dominated by the influence of Jacques Maritain) within Poulenc's artistic milieu in the 1920s and 1930s, and the model of Igor Stravinsky's conversion to Orthodox Christianity (equally attributed to "miraculous"

64 "En 1936, date capitale dans ma vie et dans ma carrière, profitant d'un séjour de travail avec Yvonne Gouverné et Bernac à Uzerche, je demandai à ce dernier de me conduire en auto à Rocamadour, dont j'avais très souvent entendu parler par mon père. Ce pèlerinage est en effet tout proche de l'Aveyron. Je venais, quelques jours avant, d'apprendre la mort tragique de mon collègue PierreOctave Ferroud. La décollation atroce de ce musicien si plein de force m’avait frappé de stupeur. Songeant au peu de poids de notre enveloppe humaine, la vie spirituelle m'attirait à nouveau. Rocamadour acheva de me ramener à la foi de mon enfance. Ce sanctuaire, sûrement le plus vieux de France (Saint Louis s'y arrêta à son départ pour la Croisade), avait tout pour me subjuguer. Accroché en plein soleil dans une vertigineuse anfractuosité de rocher, Rocamadour est un lieu de paix extraordinaire, qu'accentue encore le nombre très limité de touristes. Précédée d'une cour, toute rose de lauriers en caisse, une bien modeste chapelle, construite à moitié dans le roc, abrite une statue miraculeuse de la Vierge, sculptée, selon la tradition, dans du bois noir par saint Amadour, le petit Zachée de l'Évangile, qui dut grimper dans un arbre pour apercevoir le Christ. Le soir même de cette visite à Rocamadour, je commençai mes Litanies à la Vierge noire pour voix de femme et orgue. Dans cette oeuvre j'ai essayé de rendre le côté "dévotion paysanne" qui m’avait si fort frappé dans ce haut-lieu.... À dater de ce jour, je suis retourné bien souvent à Rocamadour, mettant sous la protection de la Vierge noire des oeuvres diverses comme Figure humaine, le Stabat, à la mémoire de mon cher Christian Bérard, et, tout récemment, l'opéra que je viens d'entreprendre d'après Les Dialogues des Carmélites de Bernanos. Vous connaissez maintenant, mon cher Claude, la véritable source d'inspiration de mon oeuvre religieuse." 
contact with a sacred icon) may all have exerted an influence on Poulenc during his initial visit to Rocamadour in 1936 (Craft and Stravinsky 1982, 26).65

One inherent limitation of all of these approaches, however, is the tendency to read Poulenc's account of his 1936 visit to Rocamadour without taking into consideration the specific contexts (whether personal or professional) that impinged upon his 1954 recollection of the event. As literary critic Paul John Eakin argued almost three decades ago, "Autobiographical truth is not a fixed but an evolving content in an intricate process of self-discovery and self-creation ...; the self that is the centre of all autobiographical narrative is necessarily a fictive structure" (Eakin 1985, 3). I would hasten to add, as Eakin himself has, that such a statement does not imply that autobiography is incapable of presenting truths. After all, Poulenc's Entretiens avec Claude Rostand was not an exercise in autobiographical hoax. In fact, the Entretiens has constituted a tremendous contribution to biography in that it provides a wealth of information about the composer's life upon which subsequent studies have been profoundly indebted. As such, the Entretiens participated in what Philippe Lejeune has referred to as "the autobiographical pact" in the way that Poulenc's reminiscences reinforce an unwritten entente between speaker and reader, that what is being said is, in fact, "the truth" (Lejeune 1974). But as Eakin argues, the mediated aspect of all autobiographical accounts points to their cultural contingency; the autobiographical act engages with materials of the past that "are shaped by memory and imagination to serve the needs of present consciousness" (Eakin 1985, 5). These needs, unsurprisingly, can take on an extraordinary range, functioning for the writer as a means of "justifying their own perceptions, upholding their reputations, disputing the accounts of others, settling scores, conveying cultural information, and inventing desirable futures, among others" (Smith and Watson 2001, 13). The autobiographical gesture, therefore, while relating a narrative of life lived, is also informed, shaped, and inflected by the concerns of its subject at a precise moment in their evolution. Ultimately, to read an autobiographical text is to read two events-the earlier time that is narrated in the autobiographical rendering, and the time during which the autobiography was actually written (Eakin 1992, 55). As Eakin reminds, "fictions and the fictionmaking process are a central constituent of the truth of any life as it is lived," and as a result lies, half-truths, exaggerations, and dissimulations all figure prominently, though not necessarily deliberately, within any act of autobiographical discourse (Eakin 1985, 5). In other words, autobiography inevitably involves storytelling, a selective manipulation of past events imagined and/or real that are rearranged and often modified over successive tellings in order to ensure specific rhetorical effects.

Poulenc's narrative of his return to Catholicism at Rocamadour should no doubt be read with these caveats in mind and with the knowledge that it too participates in a discursive strategy designed specifically to alter public opinion and to situate his music within contemporaneous early-1950s trends.

65 For general overviews concerning the imbrications of Catholicism and artistic expression in France during the interwar period, see especially Schlosser 2005; and Caron and Duchesneau 2009. 
Indeed, a comparison of the composer's correspondence from August 1936 with the Rocamadour narrative from the Entretiens is helpful in underlining the distance separating the life "as lived" and the remembered account of 1954. Despite the importance that Poulenc's moving description of his visit to Rocamadour has attained in subsequent biographical accounts, his 1936 letters suggest that his encounter with the Black Virgin may have served more precise and pragmatic goals in his professional career at that time.

Writing to Georges Auric on 25 August 1936, only three days following his first visit to Rocamadour, the composer confessed:

I don't like this period when one feels so little freedom. But I love a few people in this world, and you know the place that you have in my heart and in my life. I would like to be able to think like you, have your faith, because then we would be exactly alike, but what to do when you don't believe? If at least I had some type of faith (or belief), even the opposite (of what you have) that would be something at least, but I absolutely don't have it. Obviously we aren't living at a time when good spirits are enough to make things better. (Poulenc 1994, 425) ${ }^{66}$

Poulenc is here reflecting on Auric's support for the left-wing social and artistic political platform of the Popular Front, thanks to which he was enjoying the benefits of direct state patronage, including high-profile commissions and administrative appointments, all of which led to greater visibility for himself and his works. Indeed, the rise of the Popular Front placed Poulenc at a distinct professional disadvantage throughout 1936, and he watched with envy as friends and colleagues, including Darius Milhaud, Arthur Honegger, and Charles Koechlin, reaped the benefits of sympathizing with the regime, while Poulenc, who was decidedly "not Popular Front," was relegated to the sidelines (Poulenc 1994, 420). ${ }^{67}$ As Poulenc wrote to Henri Sauguet a few days later, as a result of its thematic contrast with the prevailing political conjuncture, he believed that the Litanies would "pack quite a punch" (427). ${ }^{68}$ Indeed, contrasting with the music of his politically engaged colleagues on the left, the religious, solemn, and archaic tone of the Litanies constituted a surprising deviation from the characteristic "good spirits" of his previous works.

Did Poulenc's turn to religious music in the late 1930 os and early 1950 constitute similar responses to crisis, namely that of aesthetically positioning himself in a manner that would distinguish his work from that of his colleagues? Was Poulenc's religious aesthetic-intensely exploited at the end of the 1930 s and the beginning of the 1950s - prompted by anxieties over professional alienation

66 Poulenc to George Auric, 25 August 1936: "Je n'aime pas cette époque où on se sent si peu libre !! Mais j'aime quelques êtres au monde et toi tu sais assez la place que tu tiens dans mon cœur et dans ma vie. J'aimerais pouvoir penser comme toi, avoir ta foi car ainsi nous serions toujours exactement au même plan mais que faire quand on ne croit pas. Si j'avais au moins une foi même contraire cela serait déjà quelque chose mais je ne l'ai absolument pas. Evidemment nous sommes à une époque où la bonne humeur ne suffit pas pour arranger les choses."

67 Poulenc to Marie-Blanche de Polignac, 15 August, 1936: "Marie-Blanche, je ne suis pas Front populaire." On music during the French Popular Front, see Moore 2006.

68 Poulenc to Henri Sauguet, 28 August 1936: "Cette œuvre en 36 est bien piquante." 
and a concomitant concern with his artistic legacy? These themes certainly emerge in the documentation treating both periods: writing to Auric in August 1936 Poulenc pessimistically wondered what would happen to his body of work if he were to "kick the bucket today" (Poulenc 1994, 425). ${ }^{69}$ Similarly, in the early 1950 s the composer was frequently beset with intense self-doubt concerning the artistic worth of his compositions. Perhaps Poulenc felt in both circumstances that by creatively exploiting the long-standing musical traditions of the church, he was more likely to see his stature improve among the critical establishment. Comments made at the end of 1950 s to his trusted confidante Simone Girard tend to confirm that the trials associated with maintaining a "serious" tone were at least in part motivated by professional ambitions: "It's not that I'm consumed by the idea of being a grrrrreat [sic] musician, but all the same it exasperated me that for so many people I was simply an erotic kleinmeister ... From the Stabat Mater to La Voix humaine I must say that it hasn't been all that amusing" (Poulenc 1994, 917)..$^{70}$

Of course, Poulenc's embrace of a religious aesthetic could also serve other purposes aside from buttressing his reputation as a "serious" composer. As Burton has proposed, the sacred theme of the "transference of grace," a central tenet of Poulenc's Catholic opera, Dialogues des Carmélites, actually held parallels with the contemporaneous dramas of Poulenc's affective life. Like the opera's main character Blanche, the composer was himself incapacitated by inexplicable fears throughout much of the composition of Dialogues; his hypochondria, like Blanche's fear of death, forced him to retreat, not to a convent of Carmelite nuns, but to the equally austere confines of a medical clinic for a week of uninterrupted slumber facilitated by heavy doses of barbiturates. Convinced he was dying of stomach cancer, Poulenc regained his psychological clarity and ability to compose only when he discovered that his lover, Lucien Roubert, was himself diagnosed with pleurisy. Like Blanche, Poulenc would find courage through the spectacle of his partner's suffering, the Dialogues growing ever closer to completion as Roubert's condition drew him ever closer to the grave. That Roubert's ultimate death was viewed by Poulenc as a necessary sacrifice for the completion of the work, a profane martyrdom that vicariously bestowed the composer with grace, cannot be doubted. Writing to Simone Girard in the fall of 1955, Poulenc carefully drew the parallels: "Lucien was delivered from his martyrdom ten days ago and the final copy of Les Carmélites was completed (take note) at the very moment my dear breathed his last. I got up from my desk and told my faithful housekeeper Anna, 'Monsieur Lucien is going to die now, because I have finished"' (Poulenc 1994, 831).71

69 Poulenc to George Auric, 25 August 1936: "Songe au vide d'une semblable œuvre une fois l'auteur disparu. Ma musique marche bien évidemment et je serais monstrueux de me plaindre d'autant plus qu'on me demande cet hiver à Belgrade, Prague, etc. ... mais je me demande si je claquais aujourd'hui si."

70 Poulenc to Simone Girard, 13 June 1959: "Ce n'est pas que je me grise d'être un grrrrrand musicien, mais tout de même cela m'horripilait d'être, pour tant de gens, un petit maître érotique ... Il faut dire que, du Stabat à La Voix on n'a pas rigolé."

${ }^{71}$ Poulenc to Simone Girard, 31 October 1955: "Lucien délivré de son martyre voici dix jours, les Carmélites achevées de recopier (lisez-moi bien) exactement à l'heure même où mon pauvre grand 
As such, religion may be viewed as functioning in Poulenc's oeuvre as an aesthetic alibi for a number of the composer's concerns (such as his professional ambitions and the challenges of his personal life) that could not be easily verbalized in the public sphere. Although the composer claimed in the Entretiens that he could think of nothing "more natural than to pray and to believe," there are indications that he never really felt at home in works that sought to express something other than the musical personality of the "jokester" (Poulenc 2011, 790). Writing to Henri Hell in 1953, he admitted that of all his works, Les Mamelles de Tirésias was definitely the one "that is dearest to me, that at heart I prefer to all others. See how alive the orchestration is, how clear and varied it sounds, and how the vocal parts stand out so well ... Perhaps the heart of the matter is that the worst of myself is the best of myself" (Poulenc 1994, 776).72 Writing to Bernac in 1954, Poulenc reiterated this sentiment, claiming that he identified with Jean, the main character of Massenet's opera Le Jongleur de Notre-Dame. A street entertainer whose lowly talents are booed by the crowd, Jean reacts to rejection by entering a monastery and devoting himself to the Virgin Mary (798). ${ }^{73}$ Indeed, when Poulenc was confronted with professional insecurity, his impulse was to repress the lure of the jokester and invest in the "serious" but arguably somewhat less instinctive realm of religious aestheticism.

\section{Conclusion}

Did such appeals to "seriousness" raise Poulenc's stature within the postwar critical community? Certainly the 1957 premiere of Dialogues des Carmélites functioned as a critical consecration amongst those most sympathetic to Poulenc's music. The composer worked hard to ensure this outcome and invited a number of critics favourable to his music (including Claude Rostand, Henri Hell, Bernard Gavoty, and Jacques Bourgeois) to the work's Milanese premiere. Dithyrambic reviews ensued, and the composer's fidelity to the austerity and sobriety of Georges Bernanos's text was generally celebrated as representing the "culmination of [Poulenc's] serious and religious tendencies."74 Despite the work's global success, the attitude adopted by the avant-garde continued to be one of polite indifference. The critical establishment most implicated in championing the revolutionary avant-garde was busy rewriting the history of twentieth-century French music, and in some of these accounts, Poulenc's contribution-“serious" or not—was completely ignored. André Hodeir's $1961 \mathrm{La}$ Musique depuis Debussy, for example, provides a portrait of twentieth-century music in which the neoclassical composers of the interwar period are relegated

rendait le dernier soupir. Je me suis levé de ma table et j'ai dit à ma fidèle Anna: 'Monsieur Lucien va mourir maintenant car j’ai fini."'

72 Poulenc to Henri Hell, 18 December 1953: "Certainement c'est l'œuvre la plus près de mon cœur, celle que dans le fond je préfère à tout. Regardez comme l'orchestration sonne claire, variée et vivante, et comme le chant se détache bien dessus ... dans le fond peut-être que le pire de moi-même est le meilleur de moi-même."

73 Poulenc to Pierre Bernac, 28 July 1954.

74 Hélène Jourdan-Morhange, "Le Dialogue des Carmélites" (sic), press clipping, n.d., Poulenc 1919-63. 
to the dustbin of history. Hodeir describes Stravinsky's neoclassical turn in the early 1920 s as an aesthetic "bankruptcy" and rhetorically employs this failure as means of better asserting the pre-eminence of serial and proto-serial writing (projected through the works of Debussy, Schoenberg, Berg, Webern, Bartok, Messiaen, Boulez, and Barraqué) as the "true" path of twentieth-century musical modernism (Hodeir, 1961, 20-22). In Hodeir's view, the interwar efforts of Les Six are barely worthy of mention, and the name of Francis Poulenc is cited only so that he can be denigrated as a composer who is not "demanding enough of the public" (84).

Hodeir's sentiment, of course, is representative of the ascendancy of serialism in the 1960 os and the movement's widely successful efforts to underline its aesthetic and technical legitimacy in relation to the music of the past. For his part, and always aware of evolving aesthetics paradigms, Poulenc did not ignore this new reality. Indeed, after reading Hodeir's book, Poulenc wrote to Henri Hell to inform him that "even if I'm not in style, I still need people to take notice of me" (Poulenc 1994, 974). Poulenc's Sept Répons de Ténèbres, written immediately following the publication of Hodeir's study, may be viewed as one of his final attempts to respond to aspects of the younger generation's musical preoccupations. Although not serialist in any real sense, the composer's twelvenote introduction to "Vendredi saint" - an eminently "serious" work-(see example 2), indicates that, like his idol Stravinsky, Poulenc was still willing to engage, albeit on a limited scale, with the aesthetic debates of the day.

Ultimately, following the Second World War, Francis Poulenc took a keen interest in the music of the French avant-garde and was compelled to react to their new aesthetic and musical proposals, whether through his music or in his prose writings. Although the music of the younger generation did not elicit a profound change in the substance of Poulenc's compositional language, he did grow to realize that the style he had embraced during the interwar period was largely out of sync with critical trends and concerns. His self-conscious aim to assert a personal form of "seriousness" in his works-one constructed with recourse to religiosity, stylistic homogeneity, and the ostensibly concomitant values of sincerity and authenticity-formed the backbone of a new tone and persona that emerged in the early 1950 s and inflected his entire body of work up to his death in 1963. Poulenc's desire to reinvent himself during this period forces us to re-examine elements of his biography, and in particular his religious turn, for the way in which they were mediated as a means of constructing his reputation in the transformed cultural context of the postwar period.

\section{ACKNOWLEDGEMENTS}

This article builds upon a conference paper, entitled "Poulenc's Conversion Revisited," which I delivered at the New York-St. Lawrence AMS Chapter Meeting at McGill University in April 2009, as well as upon a seminar presentation I gave at Keele University in March 2011. I would like to express my gratitude to the journal's anonymous reviewers, Barbara L. Kelly, Julie Pedneault-Deslauriers, and the twelve students enrolled in my seminar at the University of 


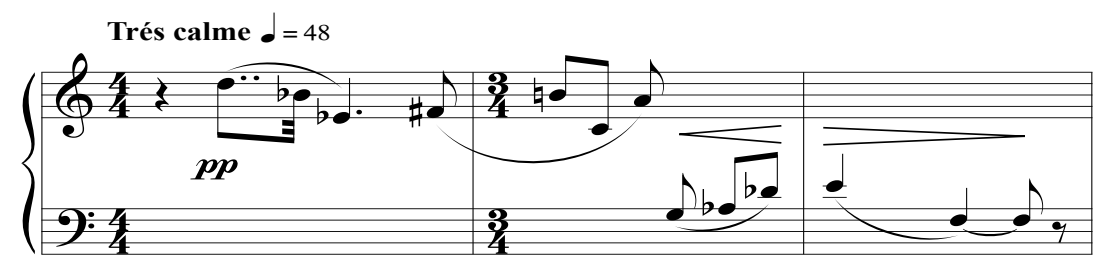

Example 2. Francis Poulenc, Sept répons des ténèbres, no. 3 "Vendredi saint-Jesum tradidit," mm. 1-3)

Ottawa entitled "Francis Poulenc en contexte" for their insights, comments, and suggestions.

\section{REFERENCES}

Audel, Stéphane, and Francis Poulenc. 1978. My Friends and Myself: Conversations with Francis Poulenc. Translated by James Harding. London: Dubson.

Burton, Richard D. 2002. Francis Poulenc. Bath: Absolute.

Caron, Sylvain, and Michel Duchesneau, eds. 2009. Musique, art et religion dans l'entre-deux-guerres. Paris: Symétrie.

Carroll, Mark. 2003. Music and Ideology in Cold War Europe. Cambridge: Cambridge University Press.

Craft, Robert, and Igor Stravinsky. 1982. Dialogues and a Diary. London: Faber \& Faber.

Colombier, Jacques de. 1953. "Le Concert de musique sacrée de la Schola Vincent d'Indy." La Gazette Provençale, 9 May.

Downes, Olin. 1947. "Furor in Paris: Poulenc's New Work at Opéra-Comique Raises a Critical Storm.” New York Times, 24 August.

Dumesnil, René. 1951. "Le festival de Strasbourg." Le Monde, 16 June.

Eakin, Paul John. 1985. Fictions in Autobiography: Studies in the Art of SelfInvention. Princeton: Princeton University Press.

- 1992. Touching the World: Reference in Autobiography. Princeton: Princeton University Press.

Fulcher, Jane F. 2005. The Composer as Intellectual: Music and Ideology in France. Oxford: Oxford University Press.

Gavoty, Bernard. 1945. "Musique et mystique: le 'cas' Messiaen.” Études (October): $21-37$.

_. 1950. "Musique française contemporaine.” Le Figaro, 27 July.

-1990. Chroniques de Clarendon, au bonheur des soirs (1945-1981). Edited by Jacques Lonchampt. Paris: Albatros.

Goléa, Antoine. 1958. Rencontres avec Pierre Boulez. Paris: Julliard.

Haine, Malou. 2004. "Mon irrésistible, insupportable et cher Poulenc ... Poulenc à travers le Journal intime de son ami Stéphane Audel." Les Cahiers du CIREM 49-51:157-227.

Hill, Peter, and Nigel Simeone. 2005. Messiaen. New Haven, CT: Yale University Press.

Hodeir, André. 1961. La Musique depuis Debussy. Paris: Presses Universitaires de France. 
Kerdyk, René. 1938. "Portrait Francis Poulenc." Gringoire, 11 February.

Launchbury, Claire. 2012. Music, Poetry, Propaganda: Constructing French Cultural Soundscapes at the BBC during the Second World War. Oxford: Peter Lang.

Leibowitz, René. 1949. Introduction à la musique de douze sons. Les "Variations pour orchestre" op. 31 d'Arnold Schoenberg. Paris: L'Arche.

Lejeune, Philippe. 1974. Le Pacte autobiographique. Paris: Seuil.

Machart, Renaud. 1995. Poulenc. Paris: Seuil.

Milhaud, Darius. 1952. Entretiens avec Claude Rostand. Paris: Julliard.

Moore, Christopher. 2006. "Music in France during the Popular Front (19351939): Politics, Aesthetics and Style." PhD diss., McGill University.

- - . 2008. "Socialist Realism and the Music of the French Popular Front." Journal of Musicology 25 (4): 473-502.

Mussulman, John A. 1979. Dear People ... Robert Shaw: A Biography. Bloomington: Indiana University Press.

Palamède. 1947. Review of Mamelles de Tirésias. Carrefour, 24 June.

Pasler, Jann. 2005. "Déconstruire d'Indy." Revue de musicologie 91 (2):369-400.

_ 2007. "Deconstructing d'Indy, or the Problem of a Composer's Reputation." 19th-Century Music 30 (3): 230-56.

Pincherle, Marc. 1945. "La Musique." Les Nouvelles littéraires, 12 April.

Poulenc, Francis. 1919-63. "Dossier de coupures de presse constitué par l'auteur." Vm Dos-10 (1-28), Département de la musique, Bibliothèque nationale de France.

—. 1954. Entretiens avec Claude Rostand. Paris: Julliard.

- 1994. Correspondance 1910-1963. Edited by Myriam Chimènes. Paris: Fayard.

_. 2006. Journal de mes mélodies. Translated by Winifred Radford. London: Kahn \& Averill.

- 2011. J'écris ce qui me chante. Edited by Nicolas Southon. Paris: Fayard.

Robert, J. P. 1954. "Francis Poulenc, musicien français ou le saint et le mauvais garçon." Gazette de Lausanne, 12 September.

Rostand, Claude. 1945. "Olivier Messiaen." Carrefour, 21 April. June.

—. 1950. "Première audition du Concerto de Francis Poulenc." Paris-Presse, 26 July.

_. 1957. Olivier Messiaen. Paris: Ventadour.

_.1963. "Francis Poulenc: Hier et demain." Le Figaro littéraire, 7 February. Roy, Jean. 1952. "Rencontre avec Stravinsky." Preuves 16 (June): 37.

Schaeffner, André. 1998. Variations sur la musique. Paris: Fayard.

Schlosser, Stephen. 2005. Jazz-Age Catholicism: Mystic Modernism in Postwar Paris, 1919-1933. Toronto: University of Toronto Press.

Schmidt, Carl B. 1995. The Music of Francis Poulenc 1899-1963. Oxford: Clarendon.

_.2010. "Francis Poulenc and Robert Shaw: A Remarkable Symbiotic Relationship." Musical Quarterly 93:329-59. 
Simeone, Nigel. 2000. "Messiaen and the Concerts de la Pléiade: 'A Kind of Clandestine Revenge against the Occupation." Music \& Letters 81 (4): 551-84.

Smith, Sidonie, and Julia Watson. 2001. Reading Autobiography: A Guide for Interpreting Life Narratives. Minneapolis: University of Minnesota Press.

Sprout, Leslie A. 2009. "The 1945 Stravinsky Debates: Nigg, Messiaen, and the Early Cold War in France." Journal of Musicology 26 (1): 85-131.

St-Aubin, Charlène. 2008. "Francis Poulenc, Nostalgia and Parisian Popular Culture." PhD diss., University of Toronto.

Tual, Denise. 1980. Le Temps dévoré. Paris: Fayard.

Vuillermoz, Émile. 1949. Histoire de la musique. Paris: Fayard.

Zed. 1951. "Le Stabat Mater de Francis Poulenc." Les dernières nouvelles d'Alsace, 16 June.

\begin{abstract}
Following the Second World War Francis Poulenc took a keen interest in the music of the French avant-garde and was compelled to react in both his music and his writings to the aesthetic and technical experiments of the younger generation. Although the music of composers like Olivier Messiaen and Pierre Boulez did not elicit a profound change on the substance of Poulenc's compositional language, he did grow to the realization that the style he had embraced during the interwar period-one generally described as light-hearted and ironic-had become largely out of sync with new critical trends and concerns. Poulenc's self-conscious aim to assert a personal form of "seriousness" in his works-one constructed with recourse to religiosity, stylistic homogeneity and the ostensibly concomitant values of sincerity and authenticity-formed the backbone of a new tone and persona that emerged following the war and which inflected his entire body of work up to his death in 1963. Poulenc's desire to reinvent himself during this period forces us to re-examine his works, writings, and elements of his biography for the way in which they were constructed as a means of facilitating the discursive emergence of this new, more "serious," persona.
\end{abstract}

\title{
RÉSUMÉ
}

Après la Deuxième Guerre mondiale, Francis Poulenc s'est intéressé à la musique de l'avant-garde française, cette dernière l'ayant amené à réagir à la fois au sein de sa musique et dans ses écrits aux expériences esthétiques et techniques de la jeune génération. Bien que la musique de compositeurs tels qu'Olivier Messiaen et Pierre Boulez n'ait pas eu un impact notable sur l'essentiel du langage musical de Poulenc, ce dernier est devenu de plus en plus conscient que le style qu'il avait développé dans l'entredeux-guerres, défini comme léger et ironique, n'était plus en phase avec les nouvelles préoccupations et tendances critiques. L'intention délibérée de Poulenc d'adopter un caractère plus sérieux dans sa musique, caractère construit sur une thématique religieuse, une homogénéité stylistique et sur les valeurs explicitement liées de sincérité et d'authenticité, est devenue la base d'un nouveau son et d'une nouvelle "persona» qui se sont développés après la guerre et ont marqué son œuvre jusqu’à sa mort en 1963. 
Le désir de Poulenc de se réinventer nous amène à réexaminer sa musique, ses écrits, certains éléments de sa vie et comment ces aspects se sont construits, afin de mieux comprendre l'émergence discursive de sa nouvelle et plus sérieuse «persona ». 